\title{
Necessary defense in crime prevention: issues of legislation and law enforcement improvement
}

\author{
Andrey Vyacheslavovich Nikulenko ${ }^{1 *}$, Maksim Andreevich Smirnov ${ }^{2}$, and Sulaymon \\ Zarobidin Muzafarov ${ }^{3}$ \\ ${ }^{1}$ The Herzen State Pedagogical University of Russia, Saint Petersburg, Russia \\ ${ }^{2}$ Prosecutor's office of Veliky Novgorod, Veliky Novgorod, Russia \\ ${ }^{3}$ Academy of the Ministry of Internal Affairs of the Republic of Tajikistan, Faculty No. 2, Department \\ of state legal disciplines, Tajikistan
}

\begin{abstract}
The article is dedicated to necessary defense as a circumstance preventing a crime in the criminal law of the Russian Federation. Goal: to identify advantages and disadvantages of regulating necessary defense as a circumstance preventing a criminal action as envisaged by Article 37 of the Criminal Code of Russia providing liability for crimes committed through excessive self-defense. Methods: a study of respective norms using a systemic method, general scientific methods (structural-functional analysis, comparison, logical method, content analysis of court practice and mass media). Primary results: the research helped to identify advantages and disadvantages of the legal framework of necessary defense as well as significant qualification mistakes of judicial and investigative practice. Conclusions and novelty of the research: insufficient efficiency of the existing approach to problems of qualifying necessary defense and ways are proposed to solve these problems, namely, by correcting the Decree of the Russian Federation Plenum of Supreme Court dated September 27, 2012, No. 19 On Judicial Use of Legislation on Necessary Defense and Causing Harm in Arrest of Perpetrators. Due to ambiguousness and inconsistent practice of using criminal law norms concerning necessary defense, it is proposed to use, in the further reconstruction of respective norms of Article 37 of the Criminal Code of the Russian Federation, a list-based approach to legislative wording of these norms that allow the defender to inflict any harm to the offender. An easily understandable wording is created, which permits lawfully causing harm to social relations protected by criminal law.

Keywords: criminal law, circumstances preventing criminality of action, necessary defense, excessive self-defense.
\end{abstract}

\section{Introduction}

Provisions resulting from the essence of Article 45 of the Russian Constitution are contained in the General Part of the Criminal Code of the Russian Federation (CC RF) describing circumstances preventing criminality of action including a right for the necessary defense of a person and citizen whose rights and law-protected interests are attacked. The necessary

\footnotetext{
*Corresponding author: nikulenkoa@mail.ru
} 
defense as a phenomenon existed at all stages of the nation and law development in Russia and other countries [2]. Moreover, the necessary defense is an instinct of any person that strives to protect against socially dangerous offenses.

At the same time, social development dictates new rules and approaches to existing legislative wordings of norms concerning necessary defense and practice of their use, which cause rather justified critical comments [1]. After CCTV systems became a part of everyday life and the human is replaced by face detection and profiling systems (intended to prevent criminal activities by profiling, e.g., identifying potentially dangerous persons based on nonverbal and operative diagnostics), staff numbers of law-enforcement authorities go down. In this manner, people often find themselves in a situation when, in case of criminal threats, they can rely only on their own and their abilities that become sufficiently limited by the existing laws that usually goes behind the realities of the modern criminogenic situation.

\section{Problem statement}

The institute of necessary defense has experienced changes corresponding to the development and improvement of law in Russia. Whatever is the legislative wording and the degree of development of legal norms in this category, the necessary defense has always been a permitting and even authorizing norm for causing harm to a person trenching upon rights and legal interests of individuals, society and state. By admitting harm to the offender as useful and permissible, the state implements an important constitutional right of people for the protection and tries to improve the legal activity of people and involve everyone into peacekeeping and crime prevention [3]. Taking into account a fine line between lawfulness and criminal nature of inflicted harm, the legislator must develop a mechanism of work and using this institute of criminal law in practice with a due level of detail and without any mistakes. Indeed, how enormous is a mistake that results in a person, who acts to protect personal rights and interests or rights and interests of another person, society or state, becoming a criminal due to incorrect interpretation of legal norms or existing legislative gaps. The importance of the institute of necessary defense [4] for citizens as the direct implementation of the constitutional right for protection of law-protected interests and as an efficient way for the state to improve citizen activity in crime prevention became the reason why the legislator and legal experts keep improving laws and legal criminal science in this area and try to fill existing gaps in legislation and evaluating categories preventing from the unambiguous interpretation of criminal norms and making judicial mistakes.

\section{$3 \quad$ Results}

The authors critically evaluate an existing situation in the prevention of socially dangerous acts and justify the need to modernize Article $37 \mathrm{CC}$ RF as non-compliant with modern criminological reality in the current wording.

The essence of this legal phenomenon includes active prevention of offense related to inflicting such damage to the offender that is formally criminally illegal and, in other circumstances, could form elements of a crime that envisages criminal liability. It is important to indicate an active nature of defense because the defense undertaken without causing harm to the offender (which is very frequent in real life) is not necessary in a criminal legal sense.

In this connection, we believe that necessary defense in a criminal legal sense is always active and intended to stop a socially dangerous offense by inflicting harm to the offender. 
The institute of necessary defense is directly related with law-enforcers who are, due to specifics of their functional and official activity, compelled to use force, special equipment and weapon to secure law-protected interests.

The poll of police officers showed that $52.5 \%$ of responders called the primary motive of insufficiently effective use of the institute of necessary defense to be a fear of undesirable consequences of such defense; $11.7 \%$ named a known negative experience of undesirable consequences; $35.8 \%$ of polled policemen named diffidence of defenders in the further correct socially legal evaluation of actions related with forced infliction of harm, namely using a weapon or special tools.

Article 28 of the Decree of the Russian Federation Plenum of Supreme Court states that law-enforcement officers, military personnel and other persons that are legally permitted to use a weapon, special tools, military and special equipment or physical force to fulfill their obligations entrusted by federal laws shall not be held criminally liable for the inflicted harm if they acted as per the requirements of laws, decrees, regulations and other statutory and regulatory enactments providing basis and procedure of using a weapon, special tools, military and special equipment or physical force ${ }^{1}$.

Successful prevention of socially dangerous offenses requires correction of the existing law-enforcement practice of judicial and investigative authorities in the qualification of actions committed for necessary defense or excessive defense one components of which can be a further specification of the text of the Decree of the Russian Federation Plenum of Supreme Court concerning this issue.

\section{Conclusion}

We believe that it is required to construct the norms of Article $47 \mathrm{CC}$ RF to make them as clear as possible for law enforcers [5], e.g., regular citizens fulfilling its civil duty related with prevention of socially dangerous offense by causing harm to the offender [6].

Article 37. Necessary defense.

1. Causing harm to an offender through necessary defense shall not be a crime in case of personal protection and protection of rights of the defender and other persons, lawprotected interests of the society or state against a socially dangerous offense if such offense is against life, health, personal freedom, sexual freedom or sexual integrity, inviolability of home, premise or other storage. These conditions of lawfulness shall also cover cases of the offense of state and/or social interests if such offense was related with causing or threatening to cause harm to the above social relations protected by criminal law as well as cases of committing a group offense or offense using weapon or items used as weapon.

2. Protection against offense not related with violence dangerous for the life of the defender or another person or with a direct threat of using such violence shall be legally acceptable if there is no excessive necessary defense, e.g., intentional actions not complying with the nature and danger of the offense. These regulations shall not cover cases envisaged by Part 1 hereof.

3. Evaluation of lawfulness of causing harm in the necessary defense shall take into account, along with the nature and degree of social danger, personal information of the offender, methods of offense, reasonable need in causing harm in defense, location and setting of offense, forces and abilities of the defender, defender's psychic condition and other circumstances related with defense.

\footnotetext{
${ }^{1}$ The Russian Federation Plenum of Supreme Court dated September 27, 2012 No. 19 On Judicial Use of Legislation on Necessary Defense and Causing Harm in Arrest of Perpetrators.
} 
4. If a person has been in a state of mental disturbance and therefore exceeded necessary defense due to unexpected offense, confusion, fright or other circumstances, it shall not be held criminally liable.

5. The excessive necessary defense shall be an intentional use of such protection method (nature of harm) by a defending person given in Part 2 hereof, which use, as obviously seemed to the defender, has not been caused by the nature and danger of the offense when the offender has been needlessly caused gross harm to health or death.

6. Provisions of this article shall fully cover all persons despite their professional and other special training or job position and an opportunity of avoiding a socially dangerous offense or seeking help from other persons or authorities. In case of conflict of norms of other legislative regulations, the provisions of this article shall be applied.

\section{$5 \quad$ Novelty}

The article gives the authors' position concerning the issue of law enforcement of necessary defense norms. The use of offensive measures to prevent socially dangerous behavior is substantiated. The authors' wording of CC RF is proposed concerning necessary defense and the draft modifications to the current version of the Russian Federation Plenum of Supreme Court dated September 27, 2012, No. 19, namely: delete words disclosing exceeding official authority by law enforcers: "can be undertaken only in case of special circumstances given in the law or bylaw (for example, use of a weapon against minors if their actions created no real danger for the life of other people").

\section{Practical relevance}

The practical relevance consists in an opportunity to improve the efficiency of the mechanism used to prevent socially dangerous actions without the use of sufficient criminally legal means.

\section{References}

1. S.V. Parkhomenko, S.F. Milyukov, A.V. Nikulenko. All-Russian Criminological Journal. 13, 992-1001 (2019). https://doi.org/10.17150/2500-4255.2019.13(6).9921001

2. N. Passas (ed.), International Crimes (Temple University, USA, 2003)

3. L. Paoli, What is the link between organized crime and drug trafficking?, in Organized Crime, Trafficking, Drugs: Selected papers presented at the Annual Conference of the European Society of Criminology, 27-30 August, Helsinki, 2003, 181-189 (2004). http://dx.doi.org/10.15496/publikation-24089

4. V.I. Omigov, Scientific Portal of the Ministry of Internal Affairs of Russia, 3, 36-44 (2008)

5. A.V. Nikulenko, Obstoyatelstva, isklyuchayushchie prestupnost deyaniya: kontseptualnye osnovy ugolovno-pravovoi reglamentatsii [Circumstances Excluding Criminality of Action: Conceptual Basics of Criminal Legal Regulation], Abstract of a $\mathrm{PhD}$ thesis in Legal Science (Saint Petersburg, 2019)

6. S.F. Milyukov, A.V. Nikulenko, Prichinenie vreda pri zaderzhanii litsa, sovershivshego obshchestvenno opasnoe deyanie [Causing Harm in Arrest of Person Who Committed a Socially Dangerous Action] (Saint Petersburg, 2015) 